\title{
The contribution of work engagement and job satisfaction to workers' psychological well-being
}

\author{
Reno Chandra Liona ${ }^{1}$, Muhammad Salis Yuniardi ${ }^{2}$ \\ ${ }^{1,2}$ Faculty of Psychology, University of Muhammadiyah Malang, Indonesia \\ 1_retjandra@gmail.com., 2 salis@umm.ac.id
}

\section{ARTICLE INFO}

Article history

Received 4 April 2020

Revised 4 July 2020

Accepted 16 July 2020

Keywords

job satisfaction

psychological well-being

work engagement

\begin{abstract}
Workers are assets to increase the productivity of the company. Workers who have a good level of psychological well-being will be able to optimize their potency and, eventually, to perform a high level of productivity. A growing body of literature suggested that workengagement and job satisfaction may affect psychological well-being. Therefore, this study aimed to investigate the relative contribution made by work engagement and job satisfaction to the psychological wellbeing of workers. Two hundred and six-nine workers $(43.9 \%$ male and $56.1 \%$ female) participated in this study, which implemented the quantitative correlational research method. Work engagement was measured using the UWES-17 (Utrecht Work Engagement Scale), job satisfaction by using The Job Satisfaction Survey, and psychological well-being using Ryff's Psychological Well-being Scales. The results from the linear regression analysis indicated that $41 \%$ of the variance could be explained by both work engagement and job satisfaction on the psychological well-being of workers. Work engagement and job satisfaction could create optimal psychological functioning and experience for workers, resulting in higher overall well-being. However, job satisfaction contributed independently to a slightly larger contribution $(22.23 \%)$ than work-engagement did (18.86\%). All in all, both work-engagement and job significantly satisfaction predicted the psychological well-being of workers.
\end{abstract}

\section{Introduction}

A worker can be defined as someone who receives a reward for work. Soh, Zarola, Palaiou, and Furnham (2016) highlighted that workers are not just a resource there to receive a salary, but have become an important capital which organizations need to manage and develop to achieve the company goals. They also suggested that a company's view of workers regarding resources in running separate companies into capital is vital for companies to find, develop, and look for optimal organizations. Workers have the potential to provide a competitive advantage for the company, and also become the main actor in using and utilizing all existing capital in the company (Soh et al., 2016). Therefore, any company should seek to optimize the performance of its workers, and this can partly be achieved, directing attention toward maintaining the psychological well-being of their workers.

Well-being refers to the optimization of an individual's psychological experiences and functioning (Ryan \& Deci, 2001). Two main aspects of well-being were identified by a broad paradigm, which is hedonic and eudemonic. Hedonic describes well-being in the concepts of life satisfaction and happiness, while eudemonic describes well-being as the concept of actualizing human potential in facing various challenges in life (Keyes, Myers, \& Kendler, 2010). The measurement of hedonic well-being is otherwise known as subjective well-being, 
which refers to the evaluation of pleasure or pain in the continuum of human experience. It consists of three components; life satisfaction, positive affect, and negative affect, which is the concept of happiness (Ryan \& Deci, 2001). In contrast, eudemonic well-being is focused on how humans can live in their daemon or true-selves, and how this will allow someone to do the most congruent activities which are suitable with the values embraced by them while thoroughly and truly involved in a task (Ryan \& Deci, 2001). The measurement of selfrealization, personal expression, and to what extent an individual can actualize their potential is also known as psychological well-being (Ryan \& Deci, 2001).

The conception of psychological well-being is an integration of human development theories, clinical theory, and the conceptions about mental health (Ryff, 1989). Ryff defined psychological well-being as an individual condition, which has positive attitudes toward oneself and others. Individuals can make their own decisions and regulate their behavior, while also creating and regulating environments that are compatible with their needs, have a purpose in life, make their life more meaningful and seek to explore and develop themself. Psychological well-being consists of six dimensions, namely, autonomy, environmental mastery, personal growth, positive relationships with others, life goals, and self-acceptance (Ryff, 1989).

According to Weiss, Westerhof, and Bohlmeijer (2016), reviews of previous empirical studies have indicated that high psychological well-being is a protective factor against mental illness and psychopathology. Furthermore, it has also been associated with biological markers of physical health, reduced risk of diseases like Alzheimer's, and affected a longer duration of life. As such, researchers and companies need to employ measurements of human psychological well-being to improve the standard of living (Weiss et al., 2016). Taking care of human health and well-being is one of the most critical factors, especially in the context of work. Based on a study conducted by Statistics Indonesia, an average minimum time people spend at work was 42 hours per week, or about more than 8 hours per day, with a lot of that time being spent working in companies or agencies (Badan Pusat Statistik, 2020). Various factors that can influence psychological well-being, such as age, sex, evaluation of certain fields, personality, socioeconomic status, culture, social support, and work ( Keyes, 1995).

Psychological well-being can additionally be defined as striving for perfection that represents the realization of one's true potential (Ryff, 1995). Since workers are the company's capital in running, developing, and achieving the organizational goals optimally, companies should pay more attention to how the workers can realize and understand their potential within the company. Psychological well-being for workers is a factor that can affect their performance and attitudes in realizing their potential, thus resulting in better performances for the company (Ryff, 1995; Hogantara \& Sintaasih, 2015).

Ryff (1989) explained that people with high psychological well-being would judge their environment as an attractive, pleasant, and challenging environment, which will make them feel happy. On the other hand, it can cause higher stress levels when their psychological well-being is low. Someone's status as a worker and how he or she perceives the work environment will affect their level of psychological well-being, and workers will become stressed easier when they have low psychological well-being. This condition will lead to workers giving bad performances and create more problems in the workplace (Soh et al., 2016). Hence, when workers feel that the work environment is interesting, fun, and full of challenges, it will make them feel comfortable and facilitate optimal performances. The workers will stay longer when they have high psychological well-being. They will also be more coordinative, more convenient to provide support to colleagues and improve time adherence in everything about the working coefficient of workers (Bartels, Peterson, \& Reina, 2019).

In addition, retirement and turnover rates are likely to increase if workers feel as though they are not tied to the organization emotionally, which is more likely to happen if 
they are not involved in their work and are unhappy in their welfare ( $\mathrm{Wu}$, Rafiq, \& Chin, 2017). There is a negative effect that happens to appear between the psychological well-being of workers who have the desire to leave their work and those who only desire to be absent from their work. Psychological well-being is also a positive effect that is influencing the workers' creativity in their work (Bartels et al., 2019). On the other hand, when workers have a strong positive feeling about their psychological well-being, this improves loyalty to what they are doing for their work. This statement was conveyed by Aiello and Tesi (2017), that positive psychological well-being is influenced by work engagement, which attracts one emotionally toward their job and empowers certain work resources such as decision authority, social support co-workers, and awards. Work engagement is a positive, fulfilling, workrelated state of mind that is characterized by vigor, dedication, and absorption (W B Schaufeli \& Bakker, 2004).

The indicators of work engagement felt by workers include the motivation to aim for challenging goals, the desire to succeed, having a personal commitment to achieving organizational goals, and a tendency to feel enthusiastic for their work, which results in better performance (Bakker \& Leiter, 2010). Organizations will benefit from their engaged workers as they become more initiative and proactive, less sick, fewer turnover intentions, show high productivity and increase customer satisfaction (Wilmar B. Schaufeli, Bakker, \& van Rhenen, 2009). On the contrary, workers who have a low level of work engagement will experience negative feelings and feel unhappy at work, and this will affect worker performance and increase emotional exhaustion (Ramdhani \& Ratnasawitri, 2017). These workers also tend to be less innovative and creative, do not want to share new ideas given with colleagues, and are more dissatisfied, less engaged, have the intention to leave the organization or company, and have high levels of stress.

Soh et al. (2016) suggested that, besides how workers are bound emotionally, another predictor that may influence well-being is how the workers regard their job in the workplace by satisfaction and dissatisfaction, usually known as job satisfaction. Job satisfaction refers to how individuals feel about their work and different aspects of the workplace (Spector, 1985). Job Satisfaction is considered as a general feeling toward work or relating to the behaviors of various elements in terms of work. Simarmata (2015) found that workers with higher job satisfaction also have higher levels of well-being. It was suggested this was because work is essential in the life of most individuals, and large amounts of time are spent working. This study also reported a positive relationship between job satisfaction and psychological well-being, in which a person with high job satisfaction will have high psychological well-being and vice versa (Simarmata, 2015).

In the preceding literature, the discussion about well-being has mainly only focused on the subjective person in responding to happiness. This study aimed to investigate psychological well-being in the context of the workplace. This study also aimed to investigate whether work engagement and job satisfaction predict psychological well-being and the extent of each relative contribution when compared with the other.

\section{Method}

\section{Research Design}

This study employed a correlational quantitative research design, which emphasized the testing of the theories by measuring the influences made between the research variables with numbers and requires data analysis with statistical procedures that contain more than one independent variable. 


\section{Participants}

Two hundred sixty-nine workers participated in this study, with slightly higher numbers of females than males (56.1\% and 43.9\%). In general, the age of participants was around 20-30 years old (78.8\%), and the rest were over the age of 40 years old. Table 1 below presents the demographics of participants in this study.

Table 1

Demographics of Participants

\begin{tabular}{rlrr}
\hline Category & Frequency & Percentage \\
\hline Sex & & & \\
1. & Male & 118 & $43.9 \%$ \\
2. & Female & 151 & $56.1 \%$ \\
Age & & & \\
1. & 20-30 Years Old & 212 & $78.8 \%$ \\
2. $31-40$ Years Old & 42 & $15.6 \%$ \\
3. 41-56 Years Old & 14 & $5.2 \%$ \\
4. More than 56 Years Old & 1 & $.4 \%$ \\
Last Education & & \\
1. Senior high school & 28 & $10.4 \%$ \\
2. Diploma & 24 & $8.9 \%$ \\
3. Bachelor & 194 & $72.1 \%$ \\
4. Postgraduate & 23 & $8.6 \%$ \\
Worker Status & & \\
1. Regular Workers & 156 & $58 \%$ \\
2. Contract Workers & 94 & $34.9 \%$ \\
3. Education Period & 12 & $4.5 \%$ \\
4. Outsourcing & 7 & $2.6 \%$ \\
Length of Work & & \\
1. Less than 1 Year & 82 & $30.5 \%$ \\
2. 1-5 Years & 142 & $52.8 \%$ \\
3. 6-10 Years & 29 & $10.8 \%$ \\
4. 11-15 Years & 13 & $4.8 \%$ \\
5. More than 15 Years & 3 & $1.1 \%$ \\
\hline
\end{tabular}

\section{Research Instruments}

Work engagement scores were recorded using the UWES-17 scale (Utrecht Work Engagement Scale) with 17 items in total, which was developed by Schaufeli, Bakker, and Salanova. The scale uses three dimensions, which are vigor, dedication, and absorption (W B Schaufeli \& Bakker, 2004). In this study, the items of the UWES-17 scale have item discrimination index ranging from $.305-.871$ and a reliability index of .933 .

Job satisfaction was measured using The Job Satisfaction Survey scale. The scale was developed based on a theory of Spector (1997) and was used to measure job satisfaction among workers. The scale consists of 36 items, developed based on nine factors: pay, promotion, supervision, fringe benefits, contingent rewards, operating conditions, coworkers, nature of work, and communication (Spector, 1985). Thirty-three final items of the job satisfaction scale have discriminating index above .300, and range from $.316-.835$ with a reliability index of .945 .

The psychological well-being of workers was measured with an instrument that was developed by Ryff (1995) with 6 (six) dimensions, which are self-acceptance, positive relation with others, autonomy, environmental mastery, and purpose in life. Thirty final items of the psychological well-being scale have discriminating index above .300, range from .324 
-.680 and with a reliability index of .920 . Table 2 shows the discrimination index and the reliability of the three scales.

Table 2

The Discrimination Index and the Reliability of the Scales

\begin{tabular}{lccc}
\hline \multicolumn{1}{c}{ Scale } & Total Items Used & $\begin{array}{c}\text { Discriminating } \\
\text { Index }\end{array}$ & Reliability \\
\hline Work Engagement & 17 & $.305-.871$ & .933 \\
Job Satisfaction & 33 & $.316-.835$ & .945 \\
Psychological Well-Being & 30 & $.324-.680$ & .920 \\
\hline
\end{tabular}

\section{Data Analysis}

The data from 269 respondents were analyzed using the Statistical Package for Social Science (SPSS) 25. Multiple linear regression analysis was conducted to test the hypothesis.

\section{Results}

Multiple regression analysis revealed that work engagement and job satisfaction had a significant contribution to psychological well-being $(F=92.572, p<.001)$. The effect of work engagement and job satisfaction simultaneously by $41 \%\left(R^{2}=.41\right)$ on the psychological wellbeing of workers.

Table 3

Result of Multiple Regression Analysis

\begin{tabular}{lcccc}
\hline \multirow{2}{*}{ Variable } & \multicolumn{3}{c}{ Psychological Well-Being } \\
\cline { 2 - 5 } & Beta & $S B B$ & $\beta$ & \multicolumn{1}{c}{$t$} \\
\hline Work Engagement & .391 & .069 & $.335^{* *}$ & 5.69 \\
\hline Job Satisfaction & .298 & .046 & $.382^{* *}$ & 6.49 \\
\hline
\end{tabular}

Note. $R^{2}=.41, F=92.572, p<.001$

$* * p<.001$ level (one-tailed)

Table 3 displays how work engagement predicts psychological well-being of workers $(\beta=.335, p<.001)$ and how job satisfaction predicts psychological well-being of workers $(\beta$ $=.382, p<.001)$. The results show that the higher the work engagement of workers, the workers would report higher levels of psychological well-being, which is also found for higher job satisfaction.

Table 4

Zero Order Correlation

\begin{tabular}{|c|c|c|c|}
\hline & $\begin{array}{l}\text { Psychological Well- } \\
\text { Being }\end{array}$ & Work Engagement & Job Satisfaction \\
\hline Psychological Well-Being & & $.563 * *$ & $.582 * *$ \\
\hline Work Engagement & $.563 * *$ & & $.599 * *$ \\
\hline Job Satisfaction & $.582 * *$ & $.599 * *$ & \\
\hline
\end{tabular}


Table 4 demonstrates that there were moderate positive correlations among variables investigated. In addition, it also suggest that the contribution of work engagement $=.335 \mathrm{x}$ $.563=.188$ or $18.86 \%$, while the contribution of job satisfaction $=.382 \times .582=.222$ or $22.23 \%$. After knowing the contribution of work engagement and also job satisfaction on psychological well-being, researchers get a statistical description of each variable.

Table 5

The Descriptive Statistic

\begin{tabular}{|c|c|c|c|c|}
\hline Category & Frequency & Percentage & Mean & Std. Deviation \\
\hline Work Engagement & & & \multirow{4}{*}{64.81} & \multirow{4}{*}{16.86} \\
\hline 1. Engaged & 124 & $47.6 \%$ & & \\
\hline 2. Not Engaged & 128 & $46.1 \%$ & & \\
\hline 3. Actively Disengaged & 17 & $6.3 \%$ & & \\
\hline \multicolumn{5}{|l|}{ Job Satisfaction } \\
\hline 1. Satisfied & 99 & $36.8 \%$ & \multirow{3}{*}{125.71} & \multirow{3}{*}{25.24} \\
\hline 2. Quite Satisfied & 167 & $62.1 \%$ & & \\
\hline 3. Not Satisfied & 3 & $1.1 \%$ & & \\
\hline \multicolumn{5}{|l|}{ Psychological Well-Being } \\
\hline 1. Well-Being & 118 & $43.9 \%$ & \multirow{3}{*}{119.09} & \multirow{3}{*}{19.70} \\
\hline 2. Quite Well-Being & 150 & $55.8 \%$ & & \\
\hline 3. Not Well-Being & 1 & $.4 \%$ & & \\
\hline
\end{tabular}

Table 5 shows that $47.6 \%$ of workers feel that they are highly engaged, and $6.3 \%$ of workers are actively disengaged, which means that workers do not feel engaged and also openly reveal that they do not like their work. This study found that workers felt quite satisfied with their company at $62.1 \%$, but there were $1.1 \%$ of workers who felt dissatisfied with their workplaces. While the results of the psychological well-being of workers were quite well-off by $55.8 \%, .4 \%$ of workers felt unequal.

\section{Discussion}

This study addressed workers' well-being with a eudemonic perspective or so-called psychological well-being. Results of the data analysis show that work engagement and job satisfaction significantly predict psychological well-being among workers. Previously, research has conducted an in-depth discussion of the psychological well-being of workers but has generally focused more on well-being. The findings from the current study imply that companies were able to enhance their workers' well-being by paying closer attention to how to maximize the workers' potential. In the work field, work engagement is an act on the part of workers to display enthusiasm, dedication, appreciation at work, and express loyalty to the job.

Meanwhile, job satisfaction is the company's responsibility to provide services matching the performance capabilities of workers. How workers feel about job satisfaction or dissatisfaction with services will result in worker performance. Furthermore, a high level of work engagement and job satisfaction will improve workers' psychological well-being. In turn, this will also be able to improve the performance, productivity, and creativity of workers in the company (Ivanović et al., 2010; Bartels et al., 2019)

Well-being related to work is best represented by four separate but related factors, namely, work stress, job satisfaction, work exhaustion, and work engagement (Rothmann, 2008). Job satisfaction indicates satisfaction and dissatisfaction in the workplace and represents the feeling that work is bad or good. Working involvement represents enthusiasm versus depression in the workplace. At the same time, the minds of depressed individuals revolve around loss and deprivation, which triggers feelings of inactivity or active in the 
workplace (Rothmann, 2008). Feelings ranging from depression to enthusiasm may be associated with a desire to move towards something that is desired (Warr, 2011). Research conducted by Soh et al. (2016) also found that work engagement and job satisfaction are factors that influence individual psychological well-being.

Based on this study, it was found that there is a positive relationship between work engagement and psychological well-being of workers, which indicates that work engagement improves the psychological well-being of workers is mirrored by low work engagement. That is, when work engagement is low, so is psychological well-being. Robertson and Cooper (2010) stated the interaction between the work engagement of the workers and their psychological well-being could lead to the creation of conditions of full involvement. In this condition, workers have a healthy psychological condition, and a high level of engagement lasts quite a long time. Healthy psychological conditions are characterized by awareness and maximum utilization of the potential of individuals, which can influence the performance of workers and have more positive feelings and thoughts about their work (Schaufeli \& Bakker, 2004).

Job satisfaction also has a positive relationship with psychological well-being. The higher job satisfaction the high psychological well-being will be. Conversely, the lower job satisfaction, the lower psychological well-being will be. This result is in accordance with the research of Yanez and Figueroa (2011), who found a positive relationship between job satisfaction and psychological well-being among Chilean prison workers. Workers who are satisfied with their work tend to feel psychologically good so that when workers have high satisfaction, psychological well-being will also be high. Workers who have good well-being will have a purpose in life, self-control, and be more social so that they look to the positive, whether in a life that is beneficial or not (Kasturi, 2016). If workers feel happy about their work, this will likely reflect the results of their duties or work. Workers with good well-being will have a purpose in life, self-control, and social, to look to the positive things, whether in a productive life or not (De Ridder \& Gillebaart, 2017).

Work engagement and job satisfaction showed a slight variation in their contribution to psychological well-being. Work engagement was $18.86 \%$, and the contribution of job satisfaction was $22.23 \%$. The total contribution of work engagement and job satisfaction to psychological well-being was $41 \%$. The results demonstrate that together, increasing the strength of these factors would have an overall positive impact on psychological well-being. Work engagement and job satisfaction are behaviors that express workers' feeling at the company, work involvement is the behavior of workers towards work that shows enthusiasm or depression, and job satisfaction is the company's behavior towards workers that show worker satisfaction or dissatisfaction (Rothmann, 2008).

Past research performed at a hospital in the United Kingdom by Soh et al. (2016) showed that work engagement, workplace tension, and job satisfaction are significant determinants of the well-being of workers at the hospital. Workers' well-being improved when workers' policies and creativity were enhanced, and it was ensured that the level of workload provided by the company could be worked on with a balance in the lives of these workers (Boxall \& Macky, 2014). Maintaining a high level of psychological well-being in the workplace, workers must pay attention to the company's physical condition, organizational culture, and both internal and external environments. It must also consider the relationships with colleagues, superiors, and clients as well as knowing the nature of work, workload, changes in a work environment, and organizational changes (Shier \& Graham, 2013). Work innovations can improve workplace performance and quality of workers' lives to create good psychological well-being (Pot, Rus, \& Oeij, 2017).

The research has a flaw found on the scale of psychological well-being; 12 items of 42 items were dropped at the time of the tryout because of the low discrimination index. Therefore, the scale of this research was still able to be revised to get optimum results for further research, consequently restructuring the statement on each item so that it can adjust to 
conditions at the workplace that are strongly recommended for future study. Also, the characteristics of respondents within this study were less specific from their age, length of work, the status of workers, and education, while all these demographic factors can affect one's psychological well-being. Older age will affect the aspects of independence and mastery of the environment, as well as issues of life goals and personal growth will decrease since early adulthood, which in this study had 212 respondents aged 20-30 years (Ryff \& Keyes, 1995). Length of work, worker status, and education also affect one's well-being because of positive feelings toward oneself and the past can also have an impact on one's state in the present (Ryff \& Singer, 1996). So further research needs to consider the characteristics of research respondents to be more confident that work engagement and job satisfaction will contribute to the psychological well-being of workers.

\section{Conclusion}

This study concludes that work engagement and job satisfaction contribute simultaneously to psychological well-being workers. Psychological well-being will be higher if these factors influence workers together rather than individually. The findings show that the psychological well-being of workers will be high if they develop their potential, by paying attention to the work engagement and job satisfaction of the workers. When workers have high psychological well-being, this will affect the level of productivity, creativity, reduce burnout, and happiness felt in the workplace.

\section{References}

Aiello, A., \& Tesi, A. (2017). Psychological well-being and work engagement among Italian social workers: Examining the mediational role of job resources. Social Work Research, 41(2), 73-83. https://doi.org/10.1093/swr/svx005

Badan Pusat Statistik. (2020). Keadaan pekerja di Indonesia (The situation of Indonesian workers). $\quad$ Retrieved from bps.go.id/publication/2020/06/19/43f6d15bcc31f4170a89e571/keadaan-pekerja-diindonesia-februari-2020.html

Bakker, A. B., \& Leiter, M. P. (2010). Work engagement: A handbook of essential theory and research. London: Psychology Press. https://doi.org/10.4324/9780203853047

Bartels, A. L., Peterson, S. J., \& Reina, C. S. (2019). Understanding well-being at work: Development and validation of the eudaimonic workplace well-being scale. PLoS ONE, 14(4). https://doi.org/10.1371/journal.pone.0215957

Boxall, P., \& Macky, K. (2014). High-involvement work processes, work intensification and employee well-being. Work, Employment and Society, 28(6), 963-984. https://doi.org/10.1177/0950017013512714

De Ridder, D., \& Gillebaart, M. (2017). Lessons learned from trait self-control in well-being: making the case for routines and initiation as important components of trait self-control. Health Psychology Review, 11(1), 89-99. https://doi.org/10.1080/17437199.2016.1266275

Hogantara, A., \& Sintaasih, D. K. (2015). Pengaruh tingkat kesejahteraan, kepuasan kerja, dan komitmen organisasi terhadap kinerja karyawan Aroma Spa, Sanur Denpasar. EJurnal Manajemen Universitas Udayana, 4(2), 336-354. Retrieved from https://www.neliti.com/publications/254983/pengaruh-tingkat-kesejahteraankepuasan-kerja-dan-komitmen-organisasi-terhadap-k\#cite

Ivanović, S., Galičić, V., \& Krstevska, G. (2010). Transformation of human resources into human capital - base for acquiring competitive advantage. Paper presented at $20^{\text {th }}$ 
Biennial International Congress Tourism \& Hospitality Industry 2010 at Opatiia, Croatia (May 2010).

Kasturi, T. (2016). Meningkatkan kesejahteraan psikologis masyarakat Indonesia: Tinjauan psikologi Islam (Enhancing psychological well-being among Indonesian community: Islamic psychology perspective). Prosiding Konferensi Nasional Peneliti Muda Psikologi Indonesia, 1 (1), 1-17. Retrieved from https://docplayer.info/70497021Meningkatkan-kesejahteraan-psikologis-masyarakat-indonesia-tinjauan-psikologiislam.html

Keyes, C. L. M., Myers, J. M., \& Kendler, K. S. (2010). The structure of the genetic and environmental influences on mental well-being. American Journal of Public Health, 100 (12)(December 2010), 2379-2384. https://doi.org/10.2105/AJPH.2010.193615

Pot, F. D., Rus, D., \& Oeij, P. R. A. (2017). Introduction: The need to uncover the field of workplace innovation. In Aligning Perspective on Health, Safety, and Wellbeing (pp. 1-8). Berlin: Springer. https://doi.org/10.1007/978-3-319-56333-6_1

Ramdhani, G. F., \& Ratnasawitri, D. (2017). Hubungan antara dukungan organisasi dengan keterikatan kerja pada karyawan PT. X di Bogor (The relationship between organisational support and work engagement among workers in PT X at Bogor). Jurnal Empati, 6(1), 199-205.

Robertson, I. T., \& Cooper, C. L. (2010). Full engagement: The integration of employee engagement and psychological well-being. Leadership and Organization Development Journal, 31 (4)(June 2010), 324-336. https://doi.org/10.1108/01437731011043348

Rothmann, S. (2008). Job satisfaction, occupational stress, burnout and work engagement as components of work-related wellbeing. SA Journal of Industrial Psychology, 34(3), 1116. https://doi.org/10.4102/sajip.v34i3.424

Ryan, R. M., \& Deci, E. L. (2001). On Happiness and human potentials: A review of research on hedonic and eudaimonic well-being. Annual Review of Psychology, 52, 141-166. https://doi.org/0066-4308/01/0201-0141\$14.00

Ryff, C. D. (1989). Happiness is everything, or is it? Explorations on the meaning of psychological well-being. Journal of Personality and Social Psychology, 57(6), 10691081. https://doi.org/10.1037/0022-3514.57.6.1069

Ryff, C. D. (1995). Psychological well-being in adult life. Current Directions in Psychological Science, 4(4), 99-104. https://doi.org/10.1111/1467-8721.ep10772395

Ryff, C. D., \& Keyes, C. L. M. (1995). The structure of psychological well-being revisited. Journal of Personality and Social Psychology, 69(4), 719-727. https://doi.org/10.1037//0022-3514.69.4.719

Ryff, C. D., \& Singer, B. (1996). Psychological well-being: Meaning, measurement, and implications for psychotherapy research. Psychotherapy and Psychosomatics, 65(1), 14-23. https://doi.org/10.1159/000289026

Schaufeli, W B, \& Bakker, A. B. (2004). Utrecht Work Engagement Scale Preliminary Manual Version 1.1. Occupational Health Psychology Unit Utrecht University, 1-60. https://doi.org/10.1037/t01350-000

Schaufeli, Wilmar B., Bakker, A. B., \& van Rhenen, W. (2009). How changes in job demands and resources predict burnout, work engagement, and sickness absenteeism. Journal of Organizational Behavior, 30(7), 893-917. https://doi.org/10.1002/job.595

Shier, M. L., \& Graham, J. R. (2013). Subjective well-being, social work, and the environment: The impact of the socio-political context of practice on social worker happiness. Journal of Social Work, 15(1), 3-23. https://doi.org/10.1177/1468017313503449

Simarmata, N. I. P. (2015). Pengaruh kepuasan kerja terhadap well-being karyawan in PT. 
Intan Havea Industry (The effect of job satisfaction on well-being among workers of PT. Intan Havea Industry). Jurnal Fakultas Psikologi Universitas HKBP Nommensen, $1(1), 44-65$.

Soh, M., Zarola, A., Palaiou, K., \& Furnham, A. (2016). Work-related well-being. Health Psychology Open, 3(1). https://doi.org/10.1177/2055102916628380

Spector, P. E. (1985). Measurement of human service staff satisfaction: Development of the Job Satisfaction Survey. American Journal of Community Psychology, 13(6), 693-713. https://doi.org/10.1007/BF00929796

Warr, P. (2011). Work Happiness and Unhappiness. New York: Psychology Press. https://doi.org/10.4324/9780203936856

Weiss, L. A., Westerhof, G. J., \& Bohlmeijer, E. T. (2016). Can we increase psychological well-being? The effects of interventions on psychological well-being: A meta-analysis of randomized controlled trials. PLoS ONE, 11(6), 1-16. https://doi.org/10.1371/journal.pone.0158092

Wu, W., Rafiq, M., \& Chin, T. (2017). Employee well-being and turnover intention: Evidence from a developing country with Muslim culture. Career Development International, 22(7), 797-815. https://doi.org/10.1108/CDI-04-2017-0072

Yanez, C. B., \& Figueroa, A. J. (2011). Psychological well-being , perceived organizational support and job satisfaction amongst Chilean prison. Rev Esp Sanid Penit, 13(February 2011), 91-99. https://doi.org/10.1590/S1575-06202011000300004 